\title{
Analysis of Indonesian Marketplace Based on Customer Satisfaction, Trust and Loyalty
}

\author{
Verry $^{1}$ and Wing Wahyu Winarno ${ }^{2}$ \\ ${ }^{1,2}$ Department of Magister Informatics Engineering \\ University of Islam Indonesia \\ Yogyakarta \\ Indonesia
}

\begin{abstract}
Indonesian people are starting to realize to make the internet one of their sources of income such as making sales in the marketplace. The public's interest in using e-commerce can be seen from the number of local and international companies trying to dominate the online market in Indonesia. Online shopping transactions in the marketplace are new experiences for people in Indonesia. The success of a marketplace can be measured based on the number of visitors and transaction volume that occurs in the marketplace. Marketplace that customers often make repeated purchases will increase the marketplace revenue. The repurchase is the main goal of the marketplace company. Many marketplace companies compete to provide the best to their customers by continuing to improve system quality, information quality, and service quality. This study aims to determine the satisfaction, trust and Loyalty factors of Marketplaces in Indonesia. This study uses the Structural Equation Modeling (SEM) model to examine 12 hypotheses in the study. The results of the study show that all of these hypotheses are accepted.
\end{abstract}

Key Words: Structural Equation Modeling, Marketplace, Satisfaction, Trust, Customer Loyalty.

\section{INTRODUCTION}

The development of information technology in Indonesia is increasingly rapid. One of them is the development of the internet. The use of the internet has become a major need for the people of Indonesia. Data from the survey conducted by the Indonesian Internet Service Providers Association (APJII) in 2017, the number of internet users in Indonesia reached 143.26 million. This number increased compared to 2016 which only reached 132.7 million. The number of internet users in 2017 covered 54.68 percent of Indonesia's total population of 262 million [1]. With this large number, more and more people have the awareness to use the internet.

The public's interest in using e-commerce can be seen from the number of local and international companies trying to dominate the online market in Indonesia [2]. E-commerce allows retailers to market products and complete transactions through the internet [3]. One form of e-commerce that is currently developing and is quite popular in Indonesia is the marketplace. According to a survey of International Data Corporation (IDC) in 2016, only 13.3 percent of them conducted online shopping transactions compared to the number of internet users in Indonesia [4]. Online shopping transactions in the marketplace are new experiences for people in Indonesia. For example, when a customer wants to buy a garment on an online shopping system, customers cannot try the clothes they want to buy like when doing offline shopping at a clothing store. Customers can only see products through the images displayed and see the quality of the product based on the specifications of the information delivered through the web or marketplace applications. Additional information that can be obtained by customers is information provided by other customers who have bought it and provided product reviews. This user experience will affect the relationship between performance, satisfaction and intention to repurchase [5].

Customer satisfaction in shopping online through a marketplace is a major concern. Satisfaction can influence other potential customers through word of mouth or electronic data such as customer reviews that have an impact on the market of their business [6]. Customers must be managed as assets, including what is needed, preferences, and customer behavior in making a purchase [7]. In addition to customer satisfaction, trust is also identified as an important factor in the success of the marketplace [8]. Trust 
greatly influences customer behavior before and after purchasing certain products. When a customer has trust in a company, they have a strong belief in the quality of the company's services [9]. The issue of loyalty also becomes very important in a fairly high marketplace competition [10]. Loyalty is defined as the attitude and commitment of customers to online retailers, which leads to repurchase behavior [11].

Some marketplace companies lose their customers in a competitive environment on the Internet because of a lack of satisfaction, trust and loyalty from customers [8]. The development of marketplace in Indonesia is happening very rapidly. In the last decade various marketplaces have emerged that offer a variety of facilities and advantages of each. The success of the marketplace is influenced by the factors that determine success so that many customers are interested. Satisfaction, trust, and loyalty are factors that determine the success of a marketplace. This study aims to determine what factors of customer satisfaction, trust, and loyalty to the marketplace in Indonesia.

\section{LITERATURE SURVEY}

There are several previous studies that can be used as references in the study about satisfaction, trust and customer loyalty of marketplace in Indonesia.

The research was titled Customer Expectation, Satisfaction and Loyalty Relationship in Turkish Airline Industry [12]. The purpose of this study was to find a relationship between customer expectations, satisfaction, and the relationship of loyalty in the airline industry in Turkey. The factors investigated are reliability, assurance, facilities, employees, flight patterns, adjustments, responsiveness, satisfaction, and customer loyalty. This study uses confimatory factor analysis (CFA) and Structural equation modeling (SEM). The results of the study show that reliability and facilities have a significant positive impact on customer satisfaction. In addition, customer satisfaction is a significant determinant of customer loyalty.

The research entitled Female online shoppers Examining the mediating roles of e-satisfaction and e-trust on e-loyalty development [13]. This study aims to determine the variables of satisfaction and trust as an intermediary factor of female customer loyalty to online stores. This research was conducted to add to the literature that discusses the relationship of loyalty, satisfaction and trust of female customers who often shop for clothes online. The factors investigated are shipping, web design, privacy, security, satisfaction, trust and loyalty. Data analysis in this study uses structural equation modeling (SEM). The results of this study indicate that privacy and security in online shopping positively affect customer trust, while web design does not influence trust. Furthermore, sending and web design have a positive effect on satisfaction. Both trust and satisfaction have a positive effect on loyalty to women who shop online.

The research entitled The impacts of corporate social responsibility, service quality, and transparency on relationship quality and customer loyalty in the hotel industry [14]. This study aims to examine whether customer perceptions of corporate social responsibility activities and transparency have an influence on the quality of relationships such as trust, satisfaction and loyalty of hotel industry customers in America. This research was conducted so that hotel managers in America are able to retain existing customers in the face of increasingly fierce competition. The method used to test the relationship between variables used confirmatory factor analysis (CFA) and strutural equation modeling (SEM). The variables investigated are social responsibility, reputation, service quality, transparency, satisfaction, trust and customer loyalty. The results of the study show that social responsibility and corporate reputation have a positive relationship to customer trust and satisfaction. While service quality has a direct effect on customer loyalty. In addition, transparency has a significant influence on customer trust. Trust has a significant positive influence on customer loyalty. The influence of satisfaction on customer loyalty is mediated by trust.

Research with the title Perceived Quality, Perceived Risk And Customer Trust Affecting Customer Loyalty Of Environmentally Friendly Electronics Products [15]. This study discusses the influence of customer perceived quality, risk and trust in customer loyalty in marketing environmentally friendly electronic products in Thailand. This research was conducted because environmentally friendly products can increase the value of the product so that it has an influence on consumer decisions. This study investigates four variables: perceived quality, perceived risk, customer trust and loyalty. Methods Data analysis uses confirmatory factor analysis (CFA) and structural equation modeling (SEM). The results showed that perceived risk and trust have a direct influence on customer loyalty. While perceived quality has an indirect effect on loyalty by mediating customer trust. In addition, the perceived quality has a direct influence on perceived risk and customer trust.

\section{METODOLOGY}

\subsection{Structural Equation Modeling (SEM)}

This study will investigate the variables that affect marketplace customer loyalty through eight independent factors, namely reliability, features, design, delivery, reputation, transparency, privacy and security, and two mediation factors, namely customer satisfaction and trust. The relationship between these variables is shown in the model like Figure 1 below. 


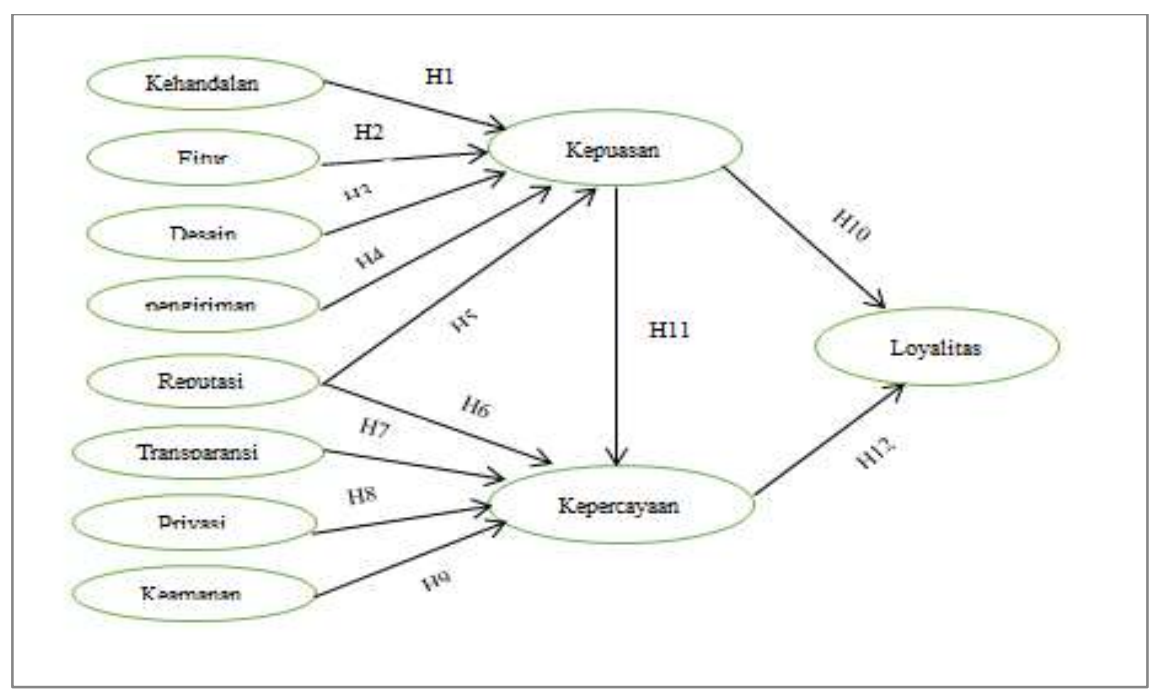

Figure1: Research Proposal Model

From the figure 1, there are 12 hypotheses, as follows:

H1: Reliability has an influence on customer satisfaction

H2: Features have an influence on Customer Satisfaction

H3: Design has an influence on Customer Satisfaction

H4: Shipping has an influence on Customer Satisfaction

H5: Reputation has an influence on Customer Satisfaction

H6: Reputation has an influence on Customer Trust

H7: Transparency has an influence on Customer Trust

H8: Privacy has an influence on Customer Trust

H9: Security has an influence on Customer Trust

H10: Customer Satisfaction has an influence on Customer Loyalty

H11: Customer Satisfaction has an influence on Customer Trust

H12: Customer trust has an influence on customer loyalty

\subsection{Research Stage}

The stages in solving problems in this study are literature studies, preparation of instruments and indicators, data collection, and data analysis as shown in figure 2. 


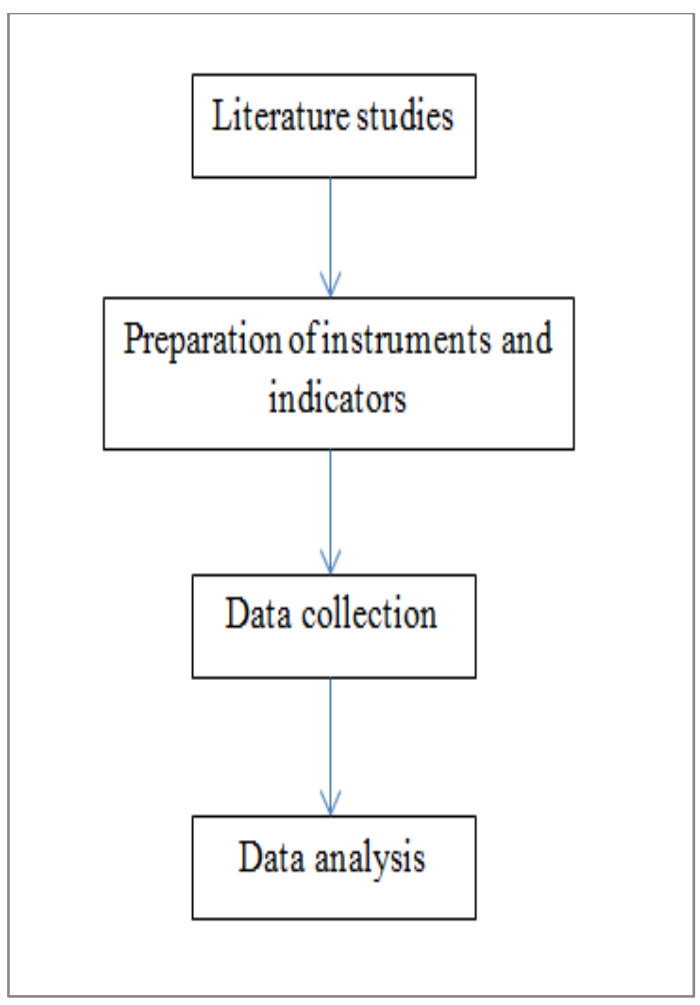

Figure 2: Research Stage

\subsection{Instruments and Indicators}

The instrument used in this research is a questionnaire containing questions from variables such as reliability, features, design, delivery, reputation, openness, privacy, security, assurance, satisfaction, trust, and loyalty. Each variable has several indicators which are represented by questions on the questionnaire. Each question consists of 5 attributes: $1=$ strongly disagree, 2 = disagree, 3 = quite agree, 4 = agree, $5=$ strongly agree. Table 1 is a list of variables, indicators, and questions on the questionnaire used.

Table1. Variables, Indicators and Questionnaire Questions

\begin{tabular}{|c|c|c|c|c|c|c|c|}
\hline \multirow{2}{*}{ Code } & \multirow{2}{*}{ Indicator } & \multirow{2}{*}{ Question } & \multicolumn{5}{|c|}{ Answer } \\
\hline & & & $\mathbf{S A}$ & $\mathbf{A}$ & $\mathbf{Q A}$ & D & SD \\
\hline \multicolumn{8}{|c|}{ 1. Reliability } \\
\hline $\mathrm{C} 11$ & Ease of Use & $\begin{array}{l}\text { The marketplace application is } \\
\text { easy to use }\end{array}$ & & & & & \\
\hline $\mathrm{C} 12$ & Response time & $\begin{array}{l}\text { The response time of each } \\
\text { process in this marketplace is } \\
\text { done quickly }\end{array}$ & & & & & \\
\hline $\mathrm{C} 13$ & Accuracy & $\begin{array}{l}\text { The information presented by } \\
\text { this marketplace is not biased or } \\
\text { misleading }\end{array}$ & & & & & \\
\hline C14 & On time & $\begin{array}{l}\text { The information presented by } \\
\text { this marketplace is not obsolete }\end{array}$ & & & & & \\
\hline $\mathrm{C} 15$ & $\begin{array}{l}\text { Service } \\
\text { Performance }\end{array}$ & $\begin{array}{l}\text { This marketplace provides } \\
\text { services as promised }\end{array}$ & & & & & \\
\hline \multicolumn{8}{|c|}{ 2. Feature } \\
\hline $\mathrm{C} 21$ & Search Engine & $\begin{array}{l}\text { This marketplace provides } \\
\text { search engines for product } \\
\text { searches }\end{array}$ & & & & & \\
\hline $\mathrm{C} 22$ & Shopping cart & $\begin{array}{l}\text { In this marketplace there is a } \\
\text { shopping cart }\end{array}$ & & & & & \\
\hline $\mathrm{C} 23$ & Payment method & $\begin{array}{l}\text { This marketplace provides } \\
\text { complete payment methods such } \\
\text { as cash on delivery (COD), }\end{array}$ & & & & & \\
\hline
\end{tabular}


International Journal of Engineering Research And Advanced Technology, Vol.5, Issue 2, February-2019

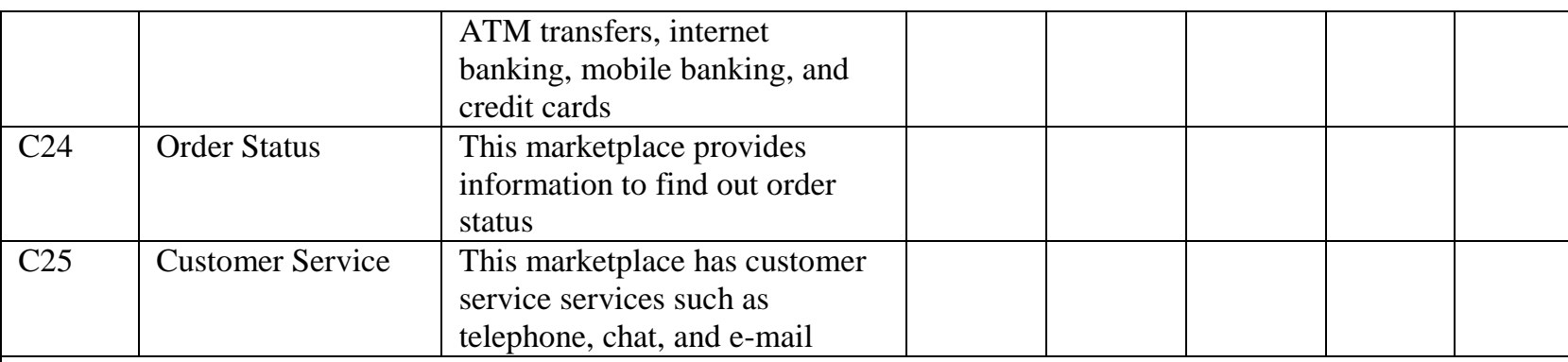

3. Design

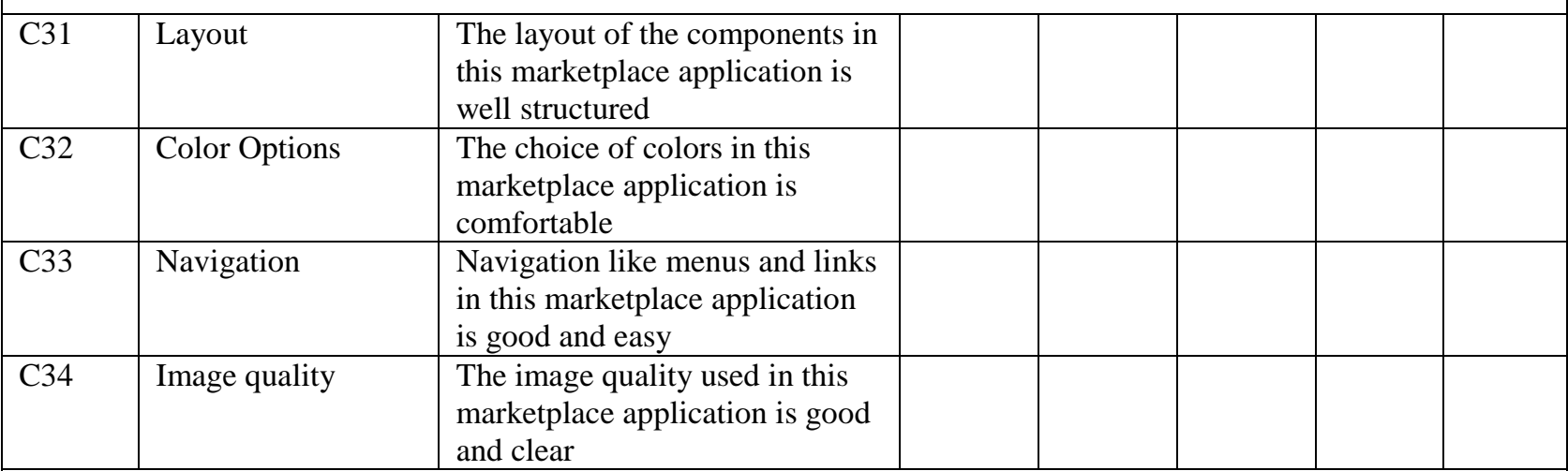

4. Shipping

\begin{tabular}{|l|l|l|l|l|l|l|}
\hline C41 & Time & $\begin{array}{l}\text { Delivering products in this } \\
\text { marketplace is on time }\end{array}$ & & & & \\
\hline C42 & Shipping agent & $\begin{array}{l}\text { This marketplace provides a } \\
\text { variety of courier options for } \\
\text { product delivery }\end{array}$ & & & & \\
\hline C43 & Shipping cost & $\begin{array}{l}\text { This marketplace provides free } \\
\text { shipping }\end{array}$ & & & & \\
\hline
\end{tabular}

5. Reputation

\begin{tabular}{|l|l|l|l|l|l|l|l|}
\hline C51 & Rating & $\begin{array}{l}\text { There are ratings from } \\
\text { customers In the marketplace }\end{array}$ & & & & \\
\hline C52 & Product quality & $\begin{array}{l}\text { The marketplace sells quality } \\
\text { products }\end{array}$ & & & & & \\
\hline
\end{tabular}

6. Transparency

\begin{tabular}{|l|l|l|l|l|l|l|l|}
\hline C61 & Review & $\begin{array}{l}\text { The marketplace provides } \\
\text { customer reviews }\end{array}$ & & & & & \\
\hline C62 & Shopping Process & $\begin{array}{l}\text { The marketplace performs a } \\
\text { clear shopping process step }\end{array}$ & & & & & \\
\hline
\end{tabular}

7. Privacy

\begin{tabular}{|l|l|l|l|l|l|l|l|}
\hline C71 & $\begin{array}{l}\text { Personal } \\
\text { information }\end{array}$ & $\begin{array}{l}\text { Thee marketplace maintains the } \\
\text { customer's personal information } \\
\text { properly and correctly }\end{array}$ & & & & \\
\cline { 1 - 6 } & & $\begin{array}{l}\text { The marketplace does not } \\
\text { provide customer personal } \\
\text { information to anyone }\end{array}$ & & & & & \\
\hline C72 & & & & & & \\
\hline
\end{tabular}

8. Security

\begin{tabular}{|l|l|l|l|l|l|l|l|}
\hline C81 & Security Level & $\begin{array}{l}\text { The marketplace has a high } \\
\text { level of security }\end{array}$ & & & & & \\
\cline { 1 - 5 } & & $\begin{array}{l}\text { The marketplace uses passwords } \\
\text { for logins and transactions }\end{array}$ & & & & & \\
\hline C82 & & & & & \\
\hline
\end{tabular}


9. Satisfaction

\begin{tabular}{|l|l|l|l|l|l|l|}
\hline C91 & Enjoy & $\begin{array}{l}\text { I am satisfied because I really } \\
\text { enjoy and love shopping in this } \\
\text { marketplace }\end{array}$ & & & & \\
\hline C92 & Convenience & $\begin{array}{l}\text { I am satisfied because I feel } \\
\text { comfortable shopping at this } \\
\text { marketplace anytime and } \\
\text { anywhere }\end{array}$ & & & & \\
\hline C93 & Advantage & $\begin{array}{l}\text { I am satisfied because shopping } \\
\text { through this marketplace I can } \\
\text { compare prices easily, choose } \\
\text { items faster and don't waste time } \\
\text { on trips to stores }\end{array}$ & & & & \\
\hline
\end{tabular}

10. Trust

\begin{tabular}{|l|l|l|l|l|l|l|}
\hline C101 & Personal & $\begin{array}{l}\text { I believe because this } \\
\text { marketplace will safeguard my } \\
\text { personal information }\end{array}$ & & & & \\
\hline C102 & Security & $\begin{array}{l}\text { I believe because this } \\
\text { marketplace has a good security } \\
\text { system }\end{array}$ & & & & \\
\hline C103 & Transparent & $\begin{array}{l}\text { I believe because the steps in } \\
\text { the shopping and payment } \\
\text { process in this marketplace are } \\
\text { easy and clear }\end{array}$ & & & & \\
\hline
\end{tabular}

11. Loyalty

\begin{tabular}{|l|l|l|l|l|l|l|}
\hline C111 & $\begin{array}{l}\text { Intention to Buy } \\
\text { Back }\end{array}$ & $\begin{array}{l}\text { I will buy again in this } \\
\text { marketplace in the future }\end{array}$ & & & & \\
\hline C112 & Recommendation & $\begin{array}{l}\text { I would recommend to other } \\
\text { people to shop at the } \\
\text { marketplace }\end{array}$ & & & & \\
\hline C113 & $\begin{array}{l}\text { Shopping } \\
\text { Experience }\end{array}$ & $\begin{array}{l}\text { I will tell others about positive } \\
\text { things about my experience } \\
\text { shopping at the marketplace }\end{array}$ & & & & \\
\hline
\end{tabular}

\section{RESULT AND ANALYSIS}

\subsection{Instrument Quality Test}

Instrument quality test is conducted to find out whether the research instrument has met the valid and reliable criteria. In this study consisted of 34 lists of statements representing each variable with the number of respondents 100 using the AMOS version 21 application. The results obtained from instrument quality testing with validity and reliability of CFA with AMOS version 21 can be seen in Table 2 below.

Table 2. Validity and Reliability Test Results

\begin{tabular}{|c|c|c|c|}
\hline Variable & Item & $\begin{array}{l}\text { Factor } \\
\text { Loading }\end{array}$ & $\begin{array}{l}\text { Construct } \\
\text { Reliability }\end{array}$ \\
\hline \multirow[t]{5}{*}{ Reliability } & $\mathrm{C} 15$ & 0,832 & \multirow{5}{*}{0,8901} \\
\hline & C14 & 0,752 & \\
\hline & C13 & 0,742 & \\
\hline & $\mathrm{C} 12$ & 0,755 & \\
\hline & $\mathrm{C} 11$ & 0,847 & \\
\hline \multirow[t]{2}{*}{ Feature } & $\mathrm{C} 25$ & 0,874 & \multirow{2}{*}{0,9052} \\
\hline & C24 & 0,872 & \\
\hline
\end{tabular}


International Journal of Engineering Research And Advanced Technology, Vol.5, Issue 2, February-2019

\begin{tabular}{|c|c|c|c|}
\hline & $\mathrm{C} 23$ & 0,821 & \\
\hline & $\mathrm{C} 22$ & 0,713 & \\
\hline & $\mathrm{C} 21$ & 0,763 & \\
\hline \multirow[t]{4}{*}{ Design } & C31 & 0,772 & \multirow{4}{*}{0,8576} \\
\hline & C32 & 0,773 & \\
\hline & C33 & 0,772 & \\
\hline & C34 & 0,784 & \\
\hline \multirow[t]{3}{*}{ Shipping } & $\mathrm{C} 43$ & 0,694 & \multirow{3}{*}{0,8937} \\
\hline & $\mathrm{C} 42$ & 0,954 & \\
\hline & $\mathrm{C} 41$ & 0,911 & \\
\hline \multirow[t]{2}{*}{ Reputation } & $\mathrm{C} 52$ & 0,795 & \multirow[b]{2}{*}{0,7858} \\
\hline & $\mathrm{C} 51$ & 0,814 & \\
\hline \multirow[t]{2}{*}{ Transparency } & C62 & 0,710 & \multirow[b]{2}{*}{0,8228} \\
\hline & C61 & 0,950 & \\
\hline \multirow[t]{3}{*}{ Satisfaction } & C93 & 0,760 & \multirow{3}{*}{0,8779} \\
\hline & $\mathrm{C} 92$ & 0,862 & \\
\hline & C91 & 0,894 & \\
\hline \multirow[t]{3}{*}{ Loyalty } & C111 & 0,667 & \multirow{3}{*}{0,7978} \\
\hline & C112 & 0,834 & \\
\hline & C113 & 0,755 & \\
\hline \multirow[t]{3}{*}{ Trust } & C101 & 0,774 & \multirow{3}{*}{0,8499} \\
\hline & C102 & 0,820 & \\
\hline & C103 & 0,831 & \\
\hline \multirow[t]{2}{*}{ Privacy } & $\mathrm{C} 72$ & 0,642 & \multirow[b]{2}{*}{0,7608} \\
\hline & C71 & 0,911 & \\
\hline \multirow[t]{2}{*}{ Security } & $\mathrm{C} 82$ & 0,989 & \multirow{2}{*}{0,8453} \\
\hline & $\mathrm{C} 81$ & 0,705 & \\
\hline
\end{tabular}

\subsection{Model Research With AMOS}

A Model that is structured on AMOS. Form Flowchart, both structural equations and measurement model equations are seen in Figure 3 below. 


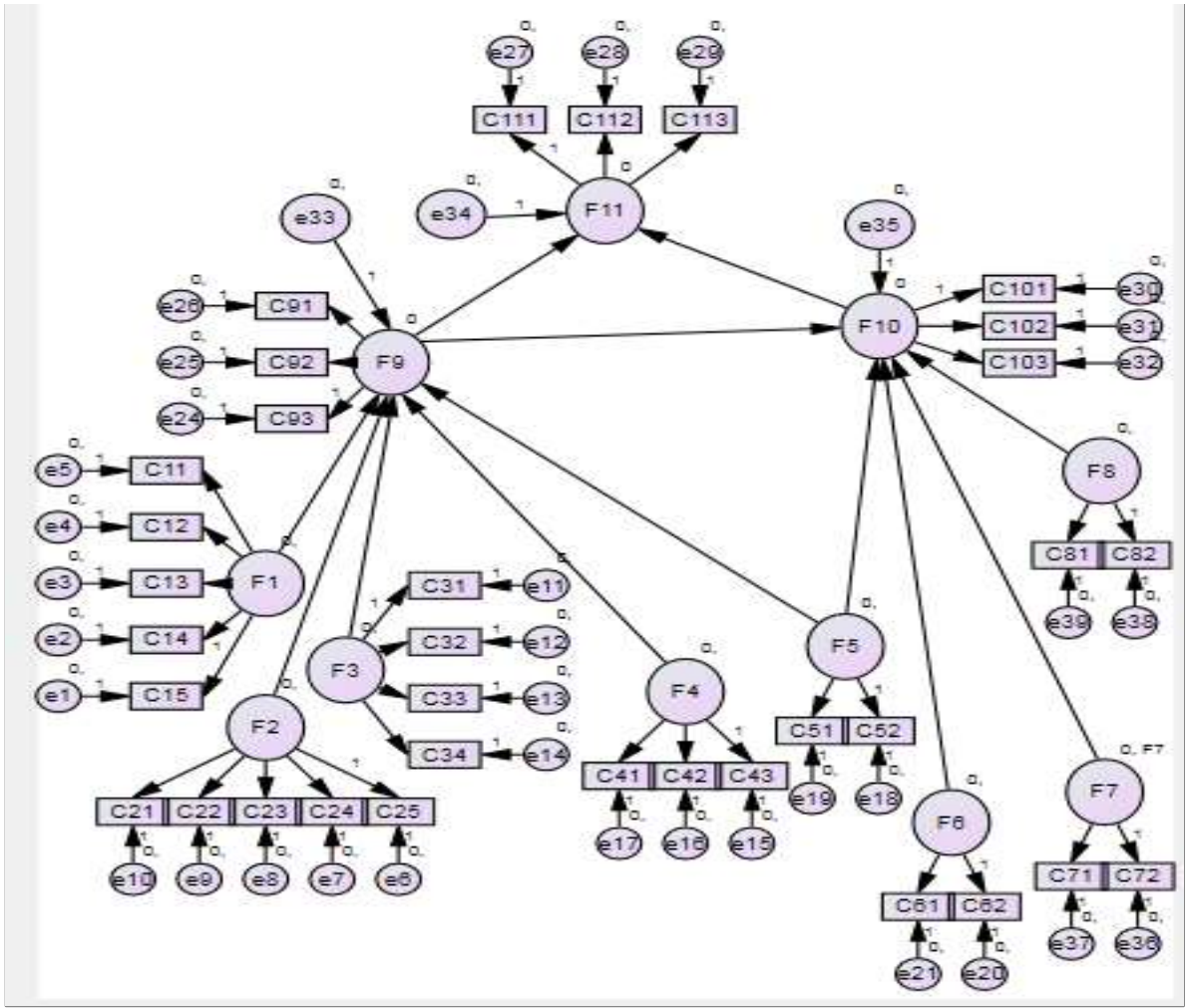

Figure 3: Model Research

\subsection{Structure Model Evaluation}

The normality test is done by comparing the $\mathrm{CR}$ value (critical ratio) at the critical assessment of normality \pm 2.58 at the 0.01 level. If there is a CR value that is greater than the critical value, the distribution of the data is not normally univariate. While multivariate can be seen in the last line c.r with the same conditions (Ghozali, 2014). The nomination shield results are shown in table 3 below.

Table 3. Normality Test

\begin{tabular}{|l|rrrrrr|}
\hline Variable & min & max & skew & c.r. & kurtosis & c.r. \\
\hline C81 & 2.000 & 5.000 & -.367 & -1.500 & .002 & .005 \\
C82 & 2.000 & 5.000 & -.061 & -.248 & -.321 & -.656 \\
C71 & 2.000 & 5.000 & -.256 & -1.045 & -.447 & -.912 \\
C103 & 2.000 & 5.000 & -.240 & -.980 & -.174 & -.354 \\
C102 & 2.000 & 5.000 & -.224 & -.913 & -.874 & -1.783 \\
C101 & 2.000 & 5.000 & -.226 & -.922 & -.625 & -1.275 \\
C113 & 2.000 & 5.000 & -.122 & -.500 & -.600 & -1.225 \\
C112 & 2.000 & 5.000 & -.085 & -.347 & -.672 & -1.372 \\
C111 & 2.000 & 5.000 & -.078 & -.317 & -.719 & -1.467 \\
C91 & 2.000 & 5.000 & -.362 & -1.479 & .053 & .108 \\
C92 & 2.000 & 5.000 & -.265 & -1.082 & -.628 & -1.282 \\
C93 & 2.000 & 5.000 & -.259 & -1.058 & -.498 & -1.016 \\
& 2.000 & 5.000 & -.234 & -.956 & -.656 & -1.340
\end{tabular}


International Journal of Engineering Research And Advanced Technology, Vol.5, Issue 2, February-2019

\begin{tabular}{|l|rrrrrr|}
\hline Variable & min & max & skew & c.r. & kurtosis & c.r. \\
\hline C61 & 2.000 & 5.000 & -.326 & -1.331 & -.183 & -.374 \\
C52 & 2.000 & 5.000 & -.123 & -.501 & -.500 & -1.020 \\
C52 & 2.000 & 5.000 & -.322 & -1.315 & -.625 & -1.276 \\
C41 & 2.000 & 5.000 & -.260 & -1.063 & -.287 & -.587 \\
C42 & 1.000 & 5.000 & -.474 & -1.935 & .428 & .875 \\
C43 & 1.000 & 5.000 & -.240 & -.980 & .189 & .385 \\
C34 & 1.000 & 5.000 & -.461 & -1.881 & .294 & .599 \\
C33 & 2.000 & 5.000 & -.272 & -1.110 & -.345 & -.703 \\
C32 & 2.000 & 5.000 & -.154 & -.628 & -.504 & -1.029 \\
C31 & 2.000 & 5.000 & -.125 & -.509 & -.371 & -.757 \\
C21 & 2.000 & 5.000 & -.189 & -.773 & -.224 & -.458 \\
C22 & 2.000 & 5.000 & -.210 & -.856 & -.456 & -.931 \\
C23 & 2.000 & 5.000 & -.287 & -1.173 & -.442 & -.901 \\
C24 & 2.000 & 5.000 & -.183 & -.746 & -.603 & -1.231 \\
C25 & 2.000 & 5.000 & -.447 & -1.825 & .018 & .037 \\
C11 & 2.000 & 5.000 & -.226 & -.922 & -.625 & -1.275 \\
C12 & 2.000 & 5.000 & -.152 & -.621 & -.506 & -1.032 \\
C13 & & & & & 6.869 & .694 \\
C14 & 2.000 & 5.000 & -.411 & -1.677 & .140 & .287 \\
C15 & & & & & & \\
\hline
\end{tabular}

After the normalization test, the next is the hypothesis test. The process of testing this statistic can be seen in the table below. From data processing, it is known that the CR value in the relationship is shown by the value above 1.96 for CR and below 0.05 for the $\mathrm{p}$ value (Ghozali, 2014). The results of the hypothesis test table are shown in Table 4 below.

Table 4. Hypothesis Test Results

\begin{tabular}{|c|l|c|c|c|c|}
\hline No & \multicolumn{1}{|c|}{ Hypothesis } & Coefficient & C.R. & $\mathbf{p}$ & Information \\
\hline $\mathbf{1}$ & F1 influence on F9 & 0,467 & 4.469 & 0,000 & There is influence \\
\hline $\mathbf{2}$ & F2 influence on F9 & 0,194 & 2.123 & 0,034 & There is influence \\
\hline $\mathbf{3}$ & F3 influence on F9 & 0,241 & 2.762 & 0,006 & There is influence \\
\hline $\mathbf{4}$ & F4 influence on F9 & $-0,082$ & -1.133 & 0,257 & There is no influence \\
\hline $\mathbf{5}$ & F5 influence on F9 & 0,453 & 3.446 & 0,000 & There is influence \\
\hline
\end{tabular}


International Journal of Engineering Research And Advanced Technology, Vol.5, Issue 2, February-2019

\begin{tabular}{|c|l|c|c|c|c|}
\hline $\mathbf{6}$ & F5 influence on F10 & 0,540 & 3.164 & 0,002 & There is influence \\
\hline $\mathbf{7}$ & F6 influence on F10 & 0,005 & 0.043 & 0,966 & There is no influence \\
\hline $\mathbf{8}$ & F9 influence on F10 & 0,367 & 2.971 & 0,003 & There is influence \\
\hline $\mathbf{9}$ & F7 influence on F10 & 0,196 & 1.555 & 0,120 & There is no influence \\
\hline $\mathbf{1 0}$ & F8 influence on F10 & $-0,213$ & -1.697 & 0,090 & There is no influence \\
\hline $\mathbf{1 1}$ & F9 influence on F11 & 0,299 & 2.571 & 0,010 & There is influence \\
\hline $\mathbf{1 2}$ & F10 influence on F11 & 0,488 & 3.273 & 0,001 & There is influence \\
\hline
\end{tabular}

Based on the table above it can be explained the relationship between variables as follows:

\section{1) F1 influence on F9}

The estimated parameter of the standardized regression weight coefficient value is 0.467 and the value of C.R 4.469 shows that the F1 and F9 relationships are positive. This means that the better F1 will increase F9. Testing the relationship between the two variables shows a probability value of $0,000(\mathrm{p}<0.05)$, so that it can be stated if there is a significant influence between F1 and F9.

\section{2) F2 influence on F9}

The estimated parameter of the standardized regression weight coefficient value is 0.194 and the value of C.R 2.123 shows that the relationship between F2 and F9 is positive. This means that the better F2 will increase F9. Testing the relationship between the two variables shows a probability value of $0.034(\mathrm{p}<0.05)$, so that it can be stated if there is a significant influence between F2 and F9.

\section{3) $\quad$ F3 influence on F9}

The estimated parameter of the standardized regression weight coefficient value is 0.241 and the value of C.R 2.762 shows that the relationship between F3 and F9 is positive. This means that the better F3 will increase F9. Testing the relationship between the two variables shows a probability value of $0.006(\mathrm{p}<0.05)$, so that it can be stated if there is a significant influence between F3 and F9.

\section{4) F4 influence on F9}

The estimated parameters of the standardized regression weight coefficient value are -0.082 and the value of C.R - 1.133 , this indicates that the relationship between F4 and F9 is negative. This means that the better F4 it will reduce F9. Testing the relationship between the two variables shows a probability value of 0.257 ( $\mathrm{p}>0.05$ ), so that it can be stated if there is no significant influence between F4 and F9.

\section{5) F5 influence on F9}

The estimated parameter of the standardized regression weight coefficient value is 0.453 and the value of C.R 3.446 shows that the relationship between F5 and F9 is positive. This means that the better F5 will increase F9. Testing the relationship between the two variables shows a probability value of 0,000 ( $p>0.05$ ), so that it can be stated if there is a significant influence between F4 and F9.

\section{6) $\quad$ 55 influence on F10}

Estimated parameters of standardized regression weight coefficient values obtained at 0.540 and the value of C.R 3.164 this shows that the relationship F5 with F10 is positive. This means that the better F5 will increase F10 Testing the relationship between the two variables shows a probability value of 0.002 ( $p>0.05$ ), so that it can be stated if there is a significant influence between F5 and F10.

\section{7) $\quad$ F6 influence on F10}

The estimated parameters of the standardized regression weight coefficient value are 0.005 and the value of C.R 0.043 shows that the relationship F6 with F10 is positive. This means that the better F6 will increase F10 Testing the relationship between the two variables shows a probability value of 0.966 ( $p>0.05$ ), so that it can be stated if there is no significant influence between F6 and F10.

\section{8) F9 influence on F10}

The estimated parameter of the standardized regression weight coefficient value is 0.367 and the value of C.R 2.971 shows that the relationship F9 with F10 is positive. This means that the better F9 it will increase F10 Testing the relationship between the two variables shows a probability value of 0.003 ( $\mathrm{p}<0.05$ ), so that it can be stated if there is a significant influence between F9 and F10.

\section{9) $\quad$ F7 influence on F10}

The estimated parameter of the standardized regression weight coefficient value is 0.196 and the value of C.R 1.555 shows that the relationship between F7 and F10 is positive. This means that the better F7 will increase F10 Testing the relationship between the two variables shows a probability value of $0.120(\mathrm{p}<0.05)$, so that it can be stated if there is no significant influence between F7 and F10. 


\section{0) F8 influence on F10}

The estimated parameters of the standardized regression weight coefficient are obtained at -0.213 and the value of C.R -1.697 , which shows that the relationship between F8 and F10 is negative. This means that the better F8 it will reduce F10. Testing the relationship between the two variables shows a probability value of $0.090(\mathrm{p}<0.05)$, so that it can be stated if there is no significant influence between F8 and F10.

\section{1) F9 influence on F11}

The estimated parameter of the standardized regression weight coefficient value is 0,299 and the value of C.R 2,571 shows that the relationship F9 with F11 is positive. This means that the better F9 will increase F11 Testing the relationship between the two variables shows a probability value of $0.010(\mathrm{p}<0.05)$, so that it can be stated if there is a significant influence between F9 and F11.

\section{2) F10 influence on F11}

The estimated parameter of the standardized regression weight coefficient value is 0.488 and the value of C.R 3.273 shows that the relationship between F10 and F11 is positive. This means that the better F10 will increase F11 Testing the relationship between the two variables shows a probability value of 0.001 ( $p>0.05)$, so that it can be stated if there is a significant influence between F10 and F11.

\section{CONCLUSSION}

Based on the results of hypothesis testing, the research that has been carried out on the determinants of satisfaction, trust and customer loyalty in the marketplace in Indonesia can be summarized as follows:

1. Test results of standardized regression weights in Hypothesis 1 namely Reliability has a significant effect on customer satisfaction. Because it has a significant value, so $\mathbf{H 1}$ is accepted.

2. The standardized regression weights test results in Hypothesis 2, which are features have a significant effect on customer satisfaction. Because it has a significant value, so $\mathbf{H} 2$ is accepted.

3. Test results of standardized regression weights in Hypothesis 3 namely Design have a significant effect on customer satisfaction. Because it has a significant value, so $\mathbf{H 3}$ is accepted.

4. Test results of standardized regression weights in Hypothesis 4 namely Delivery have a significant effect on customer satisfaction. Because it has a significant value, so $\mathbf{H} 4$ is rejected.

5. Test results of standardized regression weights in Hypothesis 5 namely Reputation have a significant effect on customer satisfaction. Because it has a significant value, so $\mathbf{H 5}$ is accepted.

6. Test results of standardized regression weights in Hypothesis 6 namely Reputation have a significant effect on customer trust. Because it has a significant value, so $\mathbf{H 6}$ is accepted.

7. The standardized regression weights test results in Hypothesis 7, namely Transparency have a significant effect on customer trust. Because it has a significant value, so $\mathbf{H 7}$ is rejected.

8. Test results of standardized regression weights in Hypothesis 8 namely Privacy have a significant effect on customer trust. Because it has a significant value, so $\mathbf{H 8}$ is rejected.

9. Test results of standardized regression weights in Hypothesis 9 namely Security have a significant effect on customer satisfaction. Because it has a significant value, so $\mathbf{H 9}$ is rejected.

10. Test results of standardized regression weights in Hypothesis 10, namely customer satisfaction has a significant effect on customer loyalty. Because it has a significant value, so H10 is accepted.

11. Test results of standardized regression weights in Hypothesis 11 namely customer satisfaction has a significant effect on customer trust. Because it has a significant value, so H11 is accepted.

12. Test results of standardized regression weights in Hypothesis 12 namely Trust have a significant effect on customer loyalty. Because it has a significant value, so $\mathbf{H 1 2}$ is accepted.

\section{REFERENCES}

[1] S. R. D. Setiawan, "tahun-2017-pengguna-internet-di-indonesia-mencapai-14326-juta-orang.," 19 February 2018. [Online]. Available: https://ekonomi.kompas.com/read/2018/02/19/161115126/tahun-2017-pengguna-internet-di-indonesia-mencapai14326-juta-orang.. [Accessed 6 March 2018]. 
[2] M. R. Sandegi, "Faktor - Faktor Keberhasilan Proses Virtualisasi Dalam Perspektif E-Commerce Di Indonesia," JURNAL INFOTEL, 2017.

[3] J.-Y. Lai, K. R. Ulhas and J.-D. Lin, "Assessing and managing e-commerce service convenience," Information Systems Frontiers, 2014.

[4] M. Nawangwulan, "baru-133-persen-pengguna-internet-indonesia-belanja-online," 21 November 2016. [Online]. Available: https://tekno.tempo.co/read/821936/baru-133-persen-pengguna-internet-indonesia-belanja-online. [Accessed 6 March 2018].

[5] I. O. Pappas, A. G. Pateli, M. N. Giannakos and V. Chrissikopoulos, "Moderating effects of online shopping experience on customer satisfaction and repurchase intentions," International Journal of Retail, pp. 187-204, 2014.

[6] B. K and S. B, "End-user Acceptance of Online Shopping Sites in India," Journal of Internet Banking and Commerce, 2015.

[7] Y.-C. Lee, Y.-C. Wang, S.-C. Lu, Y.-F. Hsieh, C.-H. Chien, S.-B. Tsai and W. Dong, "An empirical research on customer satisfaction study : a consideration of different levels of performance," SpringerPlus, 2016.

[8] N. S. Safa, "Customers repurchase intentin formatin in e-commerce," South African Journal of Informatin Management, 2016.

[9] R. Gul, "The Relationship between Reputation, Customer Satisfaction, Trust, and Loyalty," Journal of Public Administration and Governance, 2014.

[10] J. V. Chen, D. C. Yen, W. Pornpriphet and A. E. Widjaja, "E-commerce web site loyalty : A cross cultural comparison," Information Systems Frontiers, pp. 1283-1299, 2015.

[11] N. S. Safa and M. A. Ismail, "A customer loyalty formation model in electronic commerce," Economic Modelling, pp. 559564, 2013.

[12] N. Gures, S. Arslan and S. Y. Tun, "Customer Expectation, Satisfaction and Loyalty Relationship in," International Journal of Marketing Studies, pp. 66-74, 2014.

[13] S. Chou, C.-W. Chen and J.-Y. Lin, "Female online shoppers Examining the mediating roles of e-satisfaction and e-trust on e-loyalty development," Internet Research, pp. 542-561, 2015.

[14] S.-B. Kim and D.-Y. Kim, "The impacts of corporate social responsibility, service quality, and transparency on relationship quality and customer loyalty in the hotel industry," Asian Journal of Sustainability and Social Responsibility, pp. 39-55, 2016.

[15] L. Marakanon and V. Panjakajornsak, "Perceived quality, perceived risk and customer trust affecting customer loyalty of environmentally friendly electronics products," Kasetsart Journal of Social Sciences, pp. 24-30, 2017. 